\title{
WestVirginiaUniversity
}

THE RESEARCH REPOSITORY @ WVU

West Virginia Agricultural and Forestry Experiment

Davis College of Agriculture, Natural Resources

Station Bulletins

And Design

$1-1-1908$

\section{Poultry Experiments : A Record of Six Hundred Hens}

\author{
J. H. Stewart
}

Horace Atwood

Follow this and additional works at: https://researchrepository.wvu.edu/ wv_agricultural_and_forestry_experiment_station_bulletins

\section{Digital Commons Citation}

Stewart, J. H. and Atwood, Horace, "Poultry Experiments : A Record of Six Hundred Hens" (1908). West Virginia Agricultural and Forestry Experiment Station Bulletins. 115.

https://researchrepository.wvu.edu/wv_agricultural_and_forestry_experiment_station_bulletins/115 @ WVU. It has been accepted for inclusion in West Virginia Agricultural and Forestry Experiment Station Bulletins by an authorized administrator of The Research Repository @ WVU. For more information, please contact ian.harmon@mail.wvu.edu. 



\section{WEST VIRGINIA UNIVERSITY \\ AGRICULTURAL EXPERIMENT STATION \\ MORGANTOWN, W. VA.}

\section{Poultry Experiments}

A Record of Six Hundred Hens

By J. H. STEWART AND HORACE ATWOOD.

[The Bulletins and Reports of this Station will be mailed free 10 any citizen of West Virginia upon written application. Address Director of Agricultural Experiment Station, Morgantown, W. Va.] 
Hon. C. M. BABB. .Falls, W. Va. Hon. J. B. Finley...................Parkersburg, W. Va

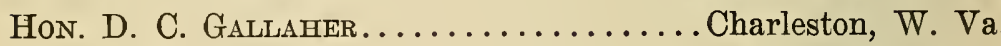

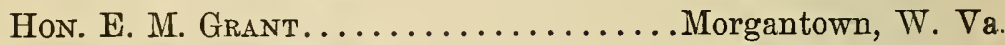
HoN. C. E. HAworTH.................Huntington, W. Va HoN. C. P. MCNELL...................Wheeling, W. Va. Hon. L. J. Williams................. Lewisburg, W. Va. Hon. T. P. JACOBS................. New Martinsville, W. Va. Hon. J. R. Trotter.................. Buckhannon, W. Va.

President of the Board of Regents.............J. R. TRotTer President of the University................. D. B. Purinton Treasurer ........................... R. WHITEHILL

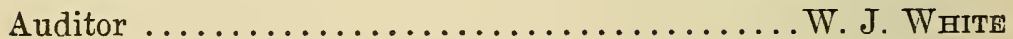

\section{STATION STAFF}

James H. Stewart, A. M......... Director and Agriculturist Bert H. Hite, M. S............. Vice Director and Chemist W. M. Munson, Рн. D...................... Horticulturist W. E. Rumser, B. S. AGr .................. Entomologist HoraCE ATwOod, M. S. AgR...........Assistant Agriculturist

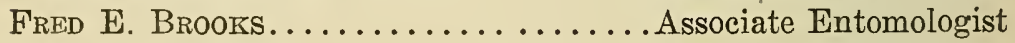
Frank B. Kunst..................... Assistant Chemist

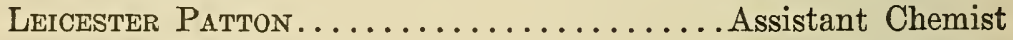
Chas. E. Weakley, JR ................. Assistant Chemist

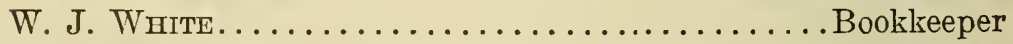
M. A. SteWart.............................Librarian Alice Engle $\ldots \ldots \ldots \ldots \ldots \ldots \ldots \ldots \ldots$. Stenographer

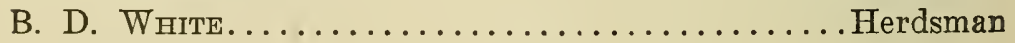


Digitized by the Internet Archive in 2010 with funding from

Lyrasis Members and Sloan Foundation 


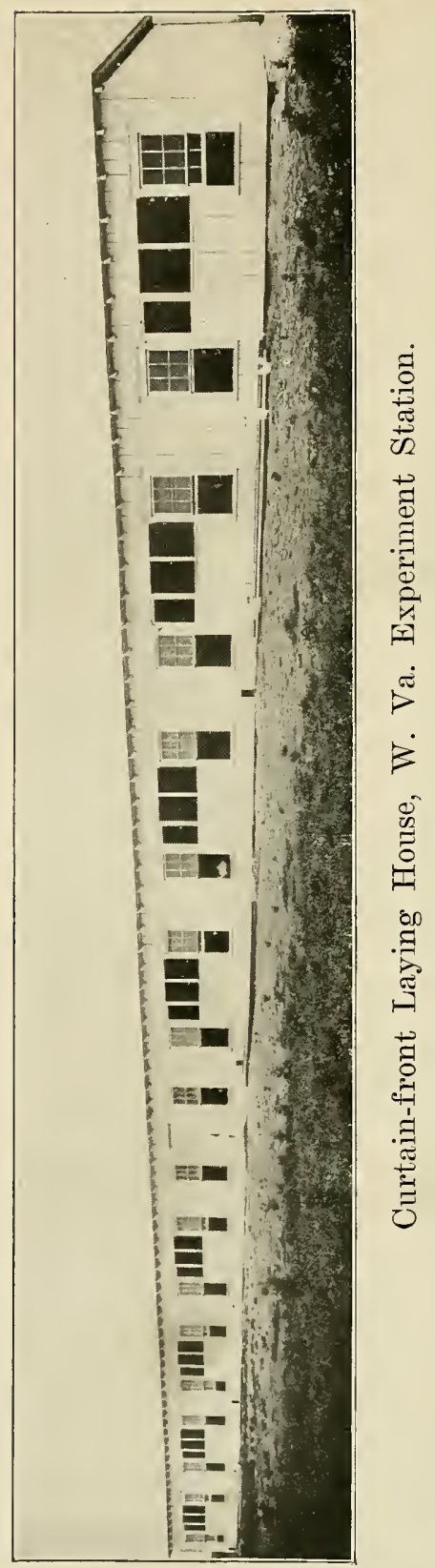


POULTRY EXPERIMENTS.

THE FIRST YEAR'S RECORD OF SIX HUNDRED HENS.

Nany people who have given the poultry industry little careful thought or attention are of the opinion that the poultry business of this 'country is relatively unimportant. Instead of this being the ease, however, this industry stands in the front rank among the standard crops and products as regards its value as a wealth producer. Indeed it may be said to lead all others in respect to the value of its products when compared with the money invested.

During the year 1907 poultry products were produced in the United States, according to the Report of the Secretary of Agriculture, to the value of $\$ 600,000,000$. This is $\$ 100,000,000$ greater than the value of the wheat crop for 1907, and exceeds the combined value of the oat crop, the potato crop, the rye crop, and the flax seed crop by $\$ 1,000,000$. Only three crops exceeded poultry products in value. These were corn, hay and cotton.

By far the greater part of the poultry products that enter into commerce are produced by the millions of small farm flocks that are scattered over the entire United States. Consequently it is quite proper that most of the studies that are carried on by the Experiment Stations for the further development of the poultry business should be directly and especially applicable to the conditions which prevail on the average farm. On the other hand, the problems that confront those who are making a specialty of poultry culture and who are keeping fowls, not by tens or twenties, but by hundreds or even thousands, shoul 3 receive a just share of attention.

When fowls are kept in large numbers what is the average egg production per fowl? How much does it cost for food? How much for labor to eare for them? What per cent of the fowls die each year? How should they be fed and handled so as to give the greatest net profit, the cost of food, the cost for 
feeding, the egg production, and the mortality all being taken into consideration?

These and many other practical questions should be studied, not only for the benefit of those who are already in the poultry business, but also for the benefit of those who are considering the advisability of establishing poultry farms and desire definite and reliable information regarding the profits that may be derived from an enterprise of this nature and how to conduct such an enterprise properly.

In order to begin the study of these questions the experiment described below has been performed.

This experiment was begun November 1st, 1906, when 600 Single Comb White Leghorn pullets were brought in from the colony houses which they had occupied during the summer on the Station farm and placed in the long laying house provided tor them.

\section{DESCRIPTION OF LAYING HOUSE.}

The house used in this test is of the curtain-front, shecroof type, 180 feet long and 16 feet wide and is divided into nine compartments, each twenty feet long, by solid board partitions. The middle compartment is reserved as a feed room.

The curtain-front laying house possesses many good features, and a brief discusson of these houses and the reasons why they are superior, in many respects, to the old form may be included here.

The curtain-front house is distinguished as shown by the frontispiece and drawings, by an opening preferably facing the south or east, which, on cold nights in winter and in stormy weather, may be closed by a frame-work covered with canvas or duck. This curtain is preferably hinged at the top and when not in use can be swung up to the roof and hooked out of the way.

In order to maintain fowls in a healthy condition it is necessary, among other things, to furnish them a dry house 
in which to roost and pure air to breathe. This is particularly true in winter when the houses, as usually built, are apt to become damp, if warmly constructed, and the air impure.

One of the most important advantages of the curtain-front house is that the house is perfectly ventilated all of the time. During stormy weather when the curtains are down the air circulates freely through the curtains, and when the weather is fine the curtain front is open and there is no tendency for the moisture present in the breath of the fowls to condense on the walls of the house and thus cause dampness. Also when the front is open the sun has unrestricted entrance, which is a distinct advantage for poultry-house windows are usually so dirty, as a result of the dust bath, that sunshine has difficulty in lighting up the interior.

Considering this kind of poultry house from a financial point of view it is cheaper than the old type of house because windows can be replaced in part by cheap duck curtains. In addition, the scratching shed is abolished, the roosting pen and scratching shed being combined, thus economizing in space and lumber.

The curtain-front house remains dry and cheerful in all sorts of weather. It is true that it is a cold house in winter when the curtains are open during the day, but fowls, when properly hardened, can endure a considerable degree of cold without injury, and this is especially true if they are in a cold atmosphere during the daytime when they are obliged to scratch vigorously for their grain.

The house in which this test was conducted faces in a southerly direction. On the front side of each section is a door and two windows and an opening, covered with wire netting, which can be closed when necessary by a cloth curtain.

The perches, which consist of "two by fours," twenty feet long, extend parallel to the north wall, which is double boarded and the space between the studs filled with shavings. Under the perches extend the dropping boards, and under this platform are located the nests as shown by the plans. In summer addi- 
tional temporary perches are installed in the front of each section elose to the opening. This gives the fowls more air on sultry nights, which is a distinct advantage.

A few months after the test began the dirt floors which were in the houses were covered with cement. This was done as follows: First the dirt was leveled and moistened. Then cement mortar consisting of one part Portland cement and three parts sand was spread directly upon the dirt, a board seveneights of an inch thick being used as a guide, when smoothing down the mortar, so as to leave the cement about an inch thick. This makes a cheap floor, keeps out rats and dampness, and can be cleaned easily when the straw litter is removed from the house.

The house was constructed of rough oak boards and roofed with three-ply tarred roofing paper. The contract price for erecting the house was $\$ 200.00$, and the house complete cost about $\$ 700.00$. The frontispiece showing the front view of the house and the working drawings will enable one to construct a house similar to this without difficulty.

\section{METHOD OF CONDUCTING THE TEST.}

The average weight of the pullets when the test began was 2.53 pounds, and the average age about five months, consequently many of them were not old enough to lay at the beginning of the experiment, and few eggs were obtained durng the first two months of the test.

\section{FEEDING.}

The floors were covered with straw litter in which the whole grain, consisting of corn and wheat, was scattered. Ground feed was fed dry in hoppers which were constantly open to the 


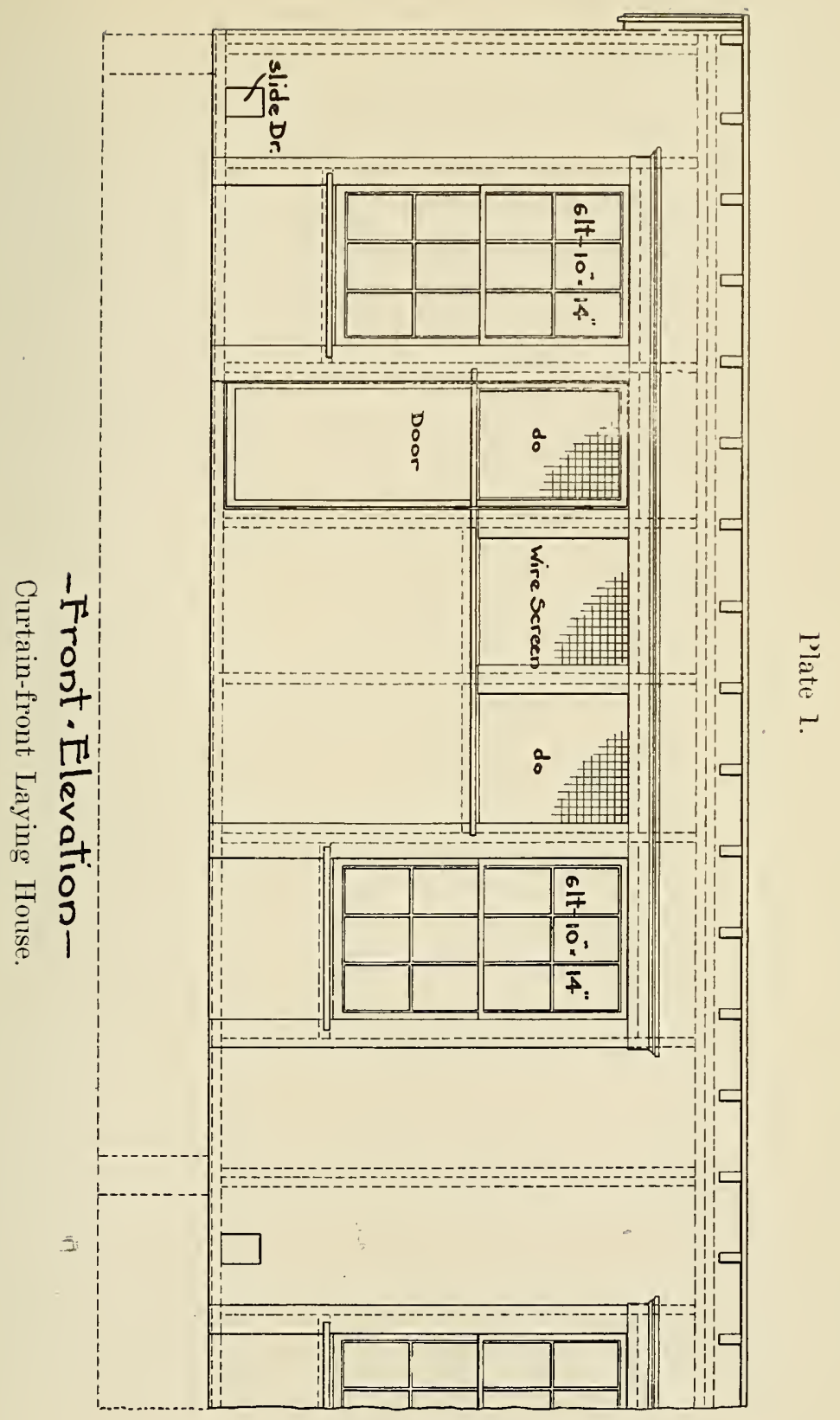




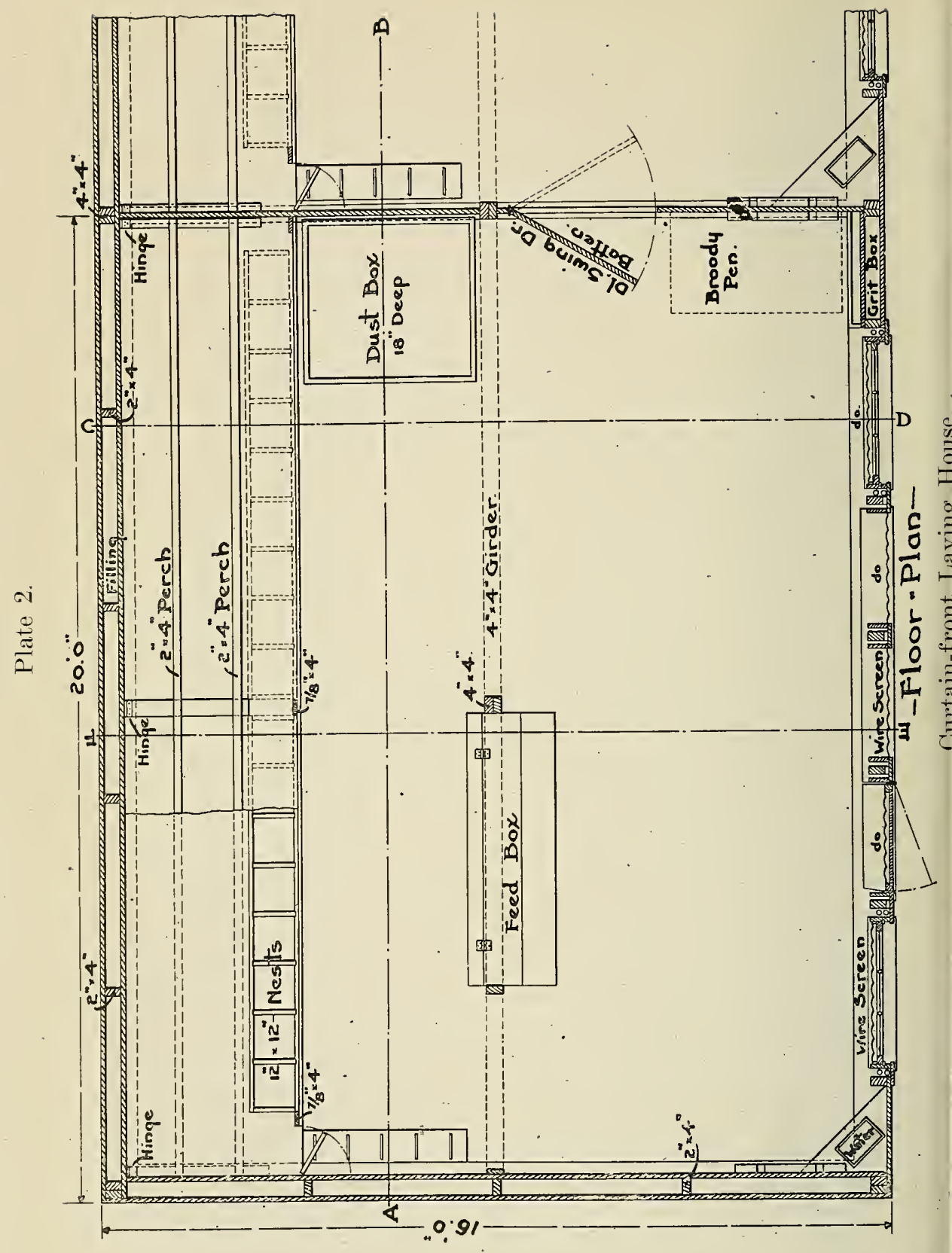


Plate?.
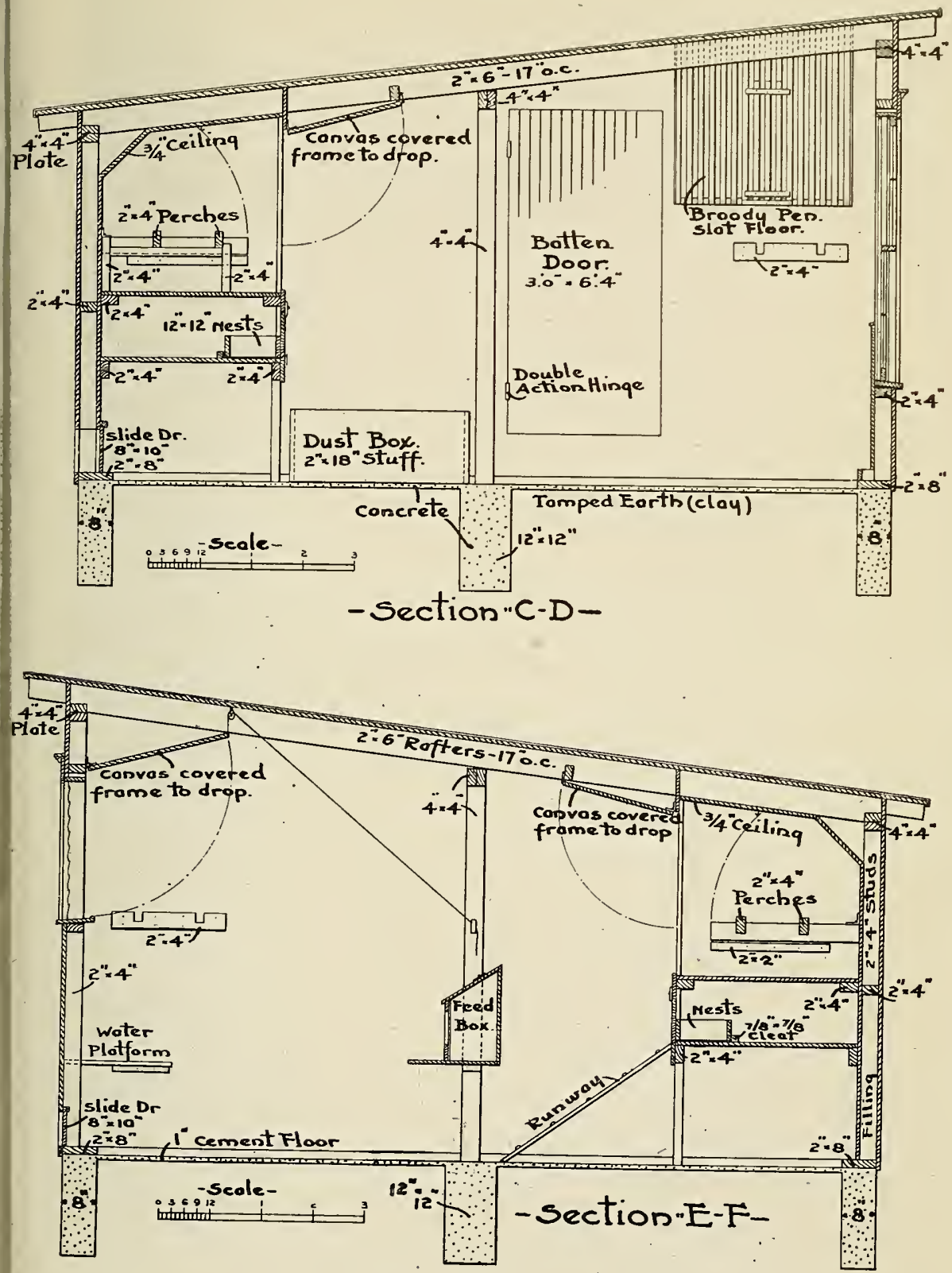


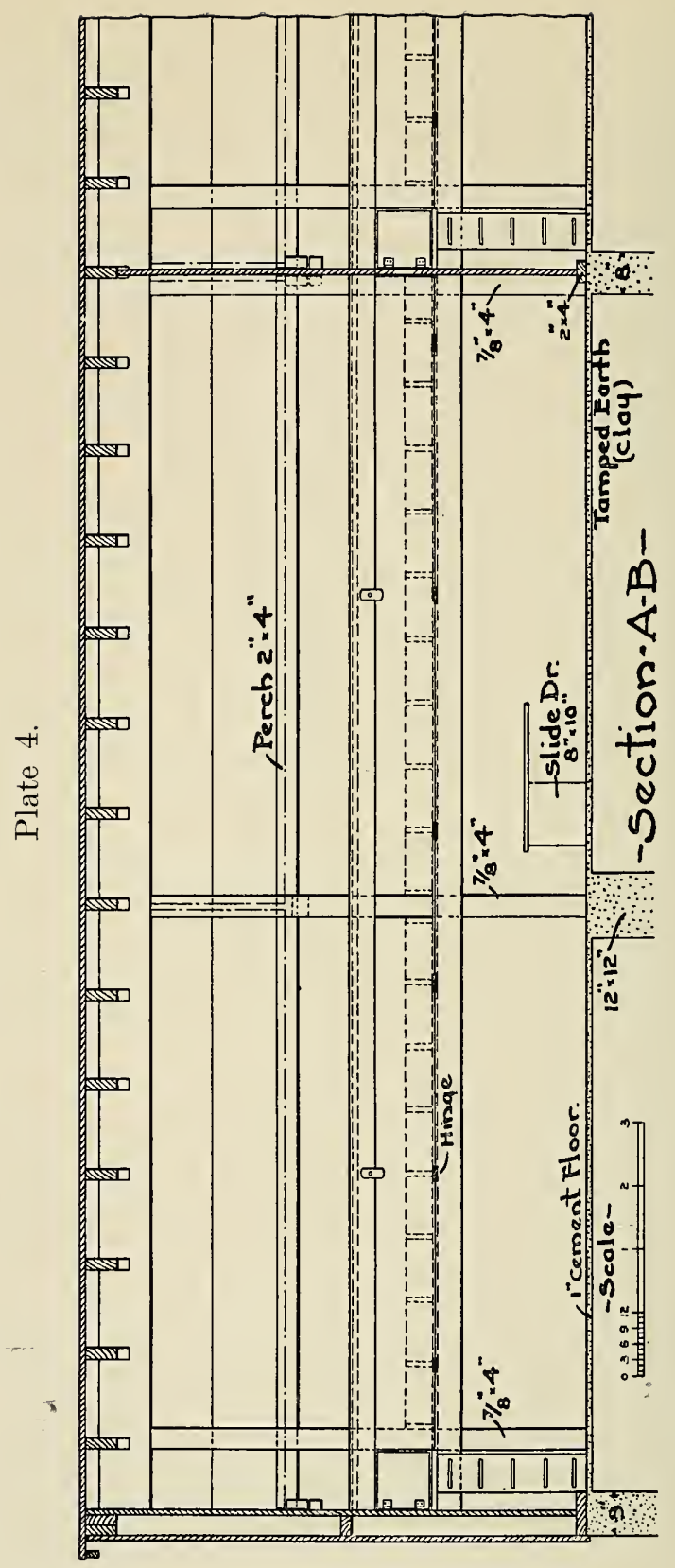




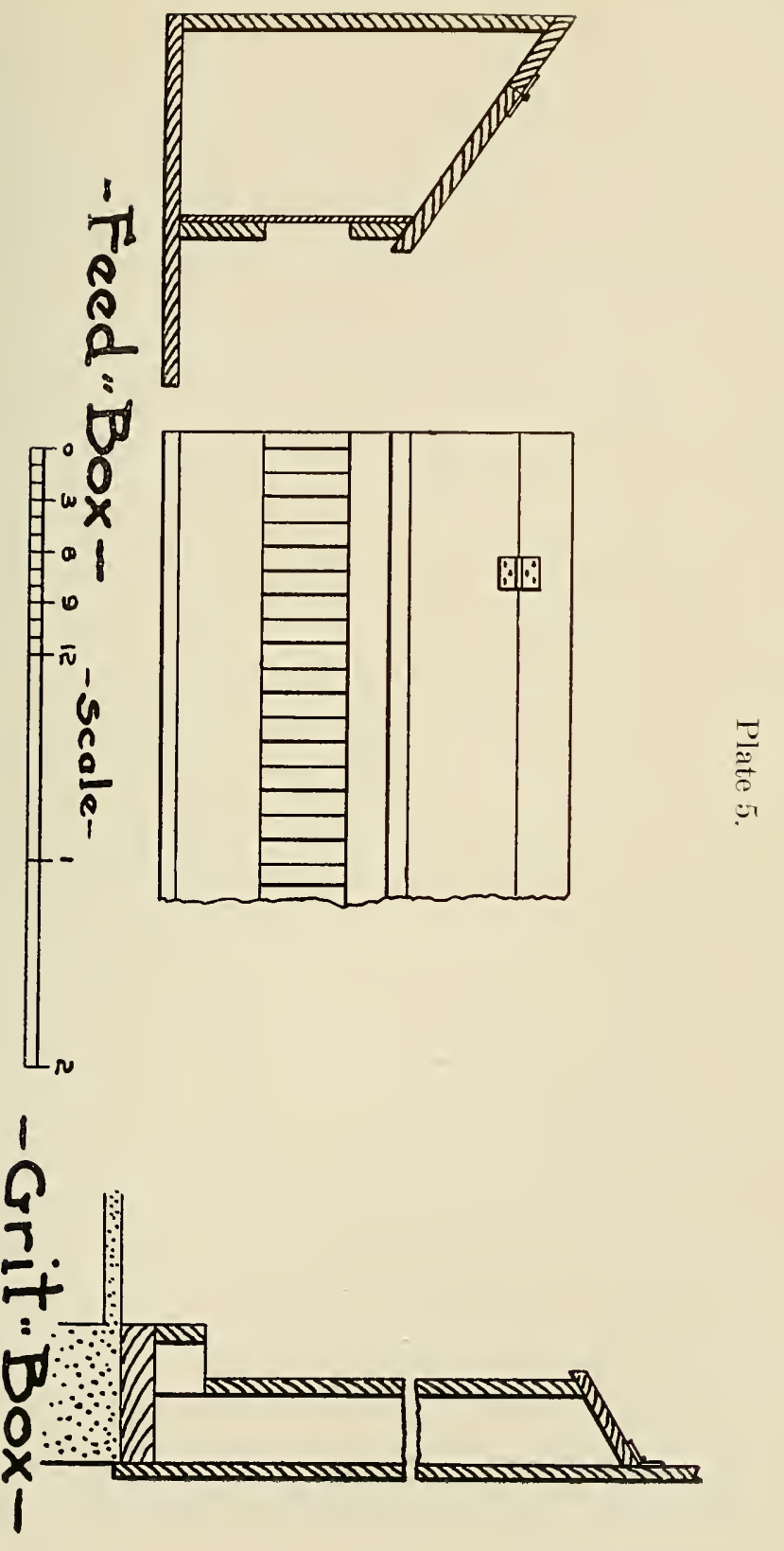



fowls. The dry mash consisted of a mixture of corn meal, wheat bran, wheat middlings, oil meal and beef scrap.

On pleasant days during fall and winter the fowls were allowed to run outside the house in one large flock where they had free range. It was thought at first that perhaps the fowls might crowd into certain rooms at night and thus cause trouble. This difficulty was entirely avoided, however, by having the small openings through which the fow pass outside, open in front of the house and in the rear, so that the forls in one section pass out in front of the house, and the forls in the next seetion pass to the rear of the house and so on. This leaves a space between each opening of 40 feet, and the fowls are much better able to find their way back to their proper division than though ali of them were let out on one side of the house. Also when the pullets were first placed in the house care was taken to let out only one pen at a time until the fowls became thoroughly aceustomed to returning to their proper roosting room. During warm weather the fowls had free range except for about three weeks in spring when it was necessary to confine them to the house so as to prevent them from scratching up some experimental plats located nearby.

\section{HEALTH OF FOWLS.}

Generally speaking the fowls remained healthy throughout the year. There was one outbreak of roup, however, which resulted in the death of several fowls which was caused, at least in part, by the attendant shutting down the inner curtains for a few nights when the weather was too warm, during the temporary absence of the writer. This caused the fowls to become too warm and as a result several caught cold and roup resulterl. If inner curtains which shut in the roosting places are used in this climate they should be used only on the coldest nights of winter when the temperature is about zero.

In addition to the deaths from roup several fowls died 
from an undetermined digestive trouble, as a result of which they become very poor. The total number of deaths during the year was fifty-four. As these died they were replaced by others of the same age.

\section{AMOUNT AND COST OF FEED.}

The feed was usually purchased in ton lots. The following table shows the amount of the various materials consumed and the cost of the same delivered at the farm.

\section{AMOUNT AND COST OF FEED CONSUMED.}

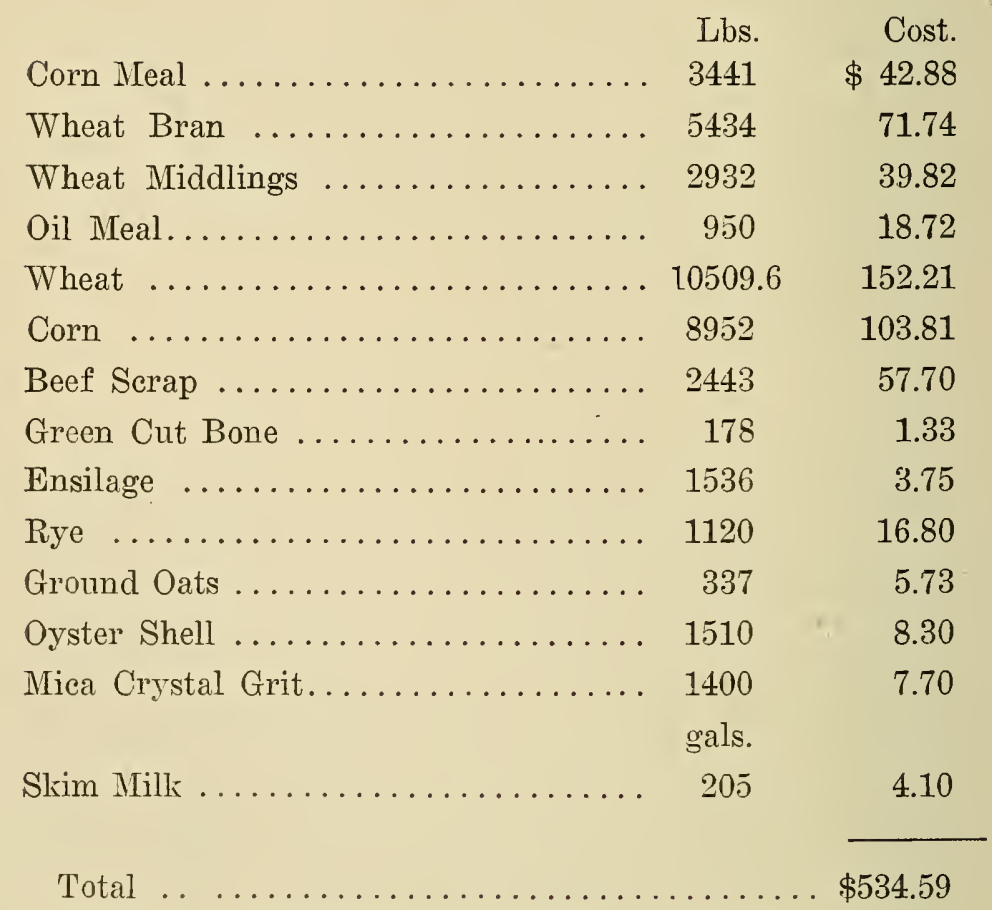


The table shows that it cost $\$ 534.59$ to feed the fowls for the year or an average of 89 cents per heal.

They consumed 36,296 pounds of grain, beef scrap, and ground fresh meat and bone, or an average of 60 pounds per head; also an average of about 5 pounds of oyster shell and grit.

The following table shows the monthly egg production for the year.

\section{NUMBER OF EGGS PRODUCED PER MONTH.}

November

December 3372

January

February

Narch

April

May

June

July

August

September

October

Total

The table shows that the highest egg production for any month was during March when the fowls averaged to lay $16 \%$ egg's per head. After that month there was a gradual dropping off in egg.production until the close of the test.

The following table shows the value of eggs produceil during the year. The prices used in this calculation are the retail 
prices which prevailed in Morgantown for strictly fresh eggs during the periods shown in the table.

\section{VALUE OF EGGS PRODUCED.}

\begin{tabular}{|c|c|c|c|}
\hline Month & $\begin{array}{l}\text { Dozen } \\
\text { Eggs }\end{array}$ & $\begin{array}{c}\text { Price } \\
\text { per Doz. }\end{array}$ & Value \\
\hline November................ & $85 \frac{3}{4}$ & $35 \check{c}$ & $\$ 30.01$ \\
\hline 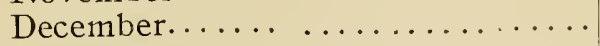 & 281 & $40 \mathrm{c}$ & 112.40 \\
\hline 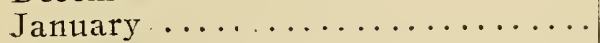 & $387 \frac{1}{12}$ & $35 \mathrm{c}$ & 135.48 \\
\hline 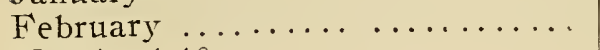 & $481 \frac{1}{1} \frac{1}{2}$ & $30 \mathrm{c}$ & 144.58 \\
\hline March $1-10$. & $231 \frac{7}{12}$ & $30 \mathrm{c}$ & 69.47 \\
\hline March $10-15 \ldots \ldots \ldots \ldots \ldots \ldots$ & $125 \frac{3}{4}$ & $22 \mathrm{c}$ & 27.66 \\
\hline March $15-31 \ldots \ldots \ldots \ldots \ldots$ & $459 \frac{\overline{3}}{4}$ & $20 \mathrm{c}$ & 91.9 อั \\
\hline April $\ldots \ldots \ldots \ldots \ldots \ldots \ldots \ldots$ & $737 \frac{1}{1} \frac{1}{2}$ & $20 \mathrm{c}$ & 147.58 \\
\hline 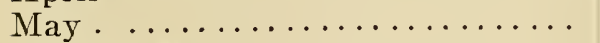 & $722 \frac{7}{12}$ & $20 \mathrm{c}$ & 144.51 \\
\hline June $1-14 \ldots \ldots \ldots \ldots \ldots \ldots \ldots$ & $295 \frac{1}{12}$ & $20 \mathrm{c}$ & 59.19 \\
\hline June $14-30 \quad \ldots \ldots \ldots \ldots \ldots \ldots$ & $321 \frac{1}{6}^{-}$ & $25 \mathrm{c}$ & 80.29 \\
\hline $\mathrm{Jully}_{\mathrm{y}} \ldots \ldots \ldots \ldots \ldots \ldots \ldots$ & $552 \frac{2}{3}$ & $25 \mathrm{c}$ & 138.16 \\
\hline August $1-26 \ldots \ldots \ldots \ldots \ldots$ & $435 \frac{5}{12}$ & $25 \mathrm{c}$ & 108.86 \\
\hline August $26-31 \ldots$. & $72 \frac{1}{2}$ & $28 \mathrm{c}$ & 20.30 \\
\hline Sept:mber $1-23 \ldots \ldots \ldots \ldots \ldots$ & 264 & $30 \mathrm{c}$ & 79.20 \\
\hline Ser tember $23-30 \ldots \ldots \ldots \ldots \ldots \ldots$ & $62 \frac{1}{3}$ & $32 \mathrm{c}$ & 19.94 \\
\hline October $1-7 \ldots \ldots \ldots \ldots \ldots \ldots$ & $46 \frac{5}{6}$ & $3 \check{c}$ & 16.39 \\
\hline October $7-31 \ldots \ldots \ldots \ldots \ldots$ & $82 \frac{1}{4}$ & $40 c$ & 32.90 \\
\hline Total & & $\ldots$. & $\$ 1,458.87$ \\
\hline
\end{tabular}

The table shows that the forls produced eggs to the total value of $\$ 1458.87$, or an average of $\$ 2.43$ per fowl. The period of lowest prices prevailed from March to June, and the highest prices during October, November and December.

\section{FINANCIAL STATEMENT.}

If we deduct from the total value of the eggs the cost for feed, then there remains a balance of $\$ 924.28$, which must cover the cost for caring for the fowls; the death losses; the deprecia- 
tion in the value of the fowls, the interest on the investment and profit.

It is difficult to estimate accurately the cost for labor, as the man who cared for these fowls did other work, but an active man could undoubtedly attend to five or six times as many fowls as were in this experiment. If we assume the lower number, also that it costs fifty dollars per month for a man to do the work, then it would cost ten dollars per month per house or one hundred and twenty dollars per year.

During the year fifty-four hens died. At eight dollars per dozen these would amount to thirty-six dollars.

If we assume that the 600 pullets were worth four hundrer! dollars at the beginning of the test and that they depreciated in value during the year twenty-five per cent then this depreciation amounts to one hundred dollars.

Assuming that the house and fowls represent an investment of eleven hundreds dollars, then the interest at six per cent amounts to sixty-six dollars, and the account stands as follows :

Income.

Expenditures.

For eggs ...... \$1458.87 For feed .......\$ 534.59

For labor ........ 120.00

For fowls which died .. 36.00

For depreciation in the value of fowls due to age ........ 100.00

For interest on investment ......... 66.00

For profit on 600 hens 602.28

The total profit from the 600 fowls was $\$ 602.28$, or practically one dollar per fowl. The total expense for the year 
was $\$ 856.58$, or $\$ 1.42$ per fowl. There were produced 5,646 dozen eggs at an average cost of fifteen cents per dozen and during the year nine per cent of the fowls died from roup or other diseases. The fowls averaged 113 eggs each. It is possible that this somewhat low egg production could have been increased by some other system of feeling, but whether the increased egg production would have more than paid for the increased cost for labor is a question for future experiments to determine. 



$$
*
$$

